\title{
MONITORING OF THE RIVERBEDS OF RIVERS DNIESTER AND TISZA OF THE
} CARPATHIAN REGION

\author{
Kh. Burshtynska, V. Shevchuk, S. Tretyak, V. Vekliuk \\ Department of Photogrammetry and Geoinformatics of National University Lviv Polytechnic, Lviv, Ukraine - \\ byrsht@polynet.lviv.ua, aspirantvov08@rambler.ru
}

Commission VII, WG VII/4

KEY WORDS: Channel processes, Monitoring, Flooding, Displacement of Channels, Space images, Topographic maps.

\begin{abstract}
:
The paper analyses the causes of riverbed shifts of the rivers Dniester and Tisza of the Carpathian region. Among these reasons are mostly climate, physical and geographical, and anthropogenic factors, including frequent floods, weak rocks and soils, logging, and removal of gravel and sand materials out of the channels. The research considers the transition of the Dniester and Tisza rivers from mountaineous area into the lowland. The analysis of these shifts has been carried out on the $100 \mathrm{~km}$ long sections over a $100-$ year period. We used topographic maps and space images, as well as special geological and soil maps, as materials for this research. We have determined that the shifts of the Dniester and Tisza riverbeds can reach up to $500-1000 \mathrm{~m}$ in some sections. We also analyze the risks and dangers that follow such shifts.
\end{abstract}

\section{INTRODUCTION}

The last decades in Ukraine have been marked by a rapid increase of catastrophic floods, as well as social and economic losses that accompany them.

Long-term observations over the hydrological regime of rivers show that the most catastrophic hydrological effects, which are responsible for serious harms to welfare of the country and its population, usually happen in the highlands of the Carpathian mountains. In 20th century the floods happened in the north-east slope of the Carpathians in warmer season in1911, 1927, 1941, 1955, 1969, 1980, 1984, 1989,1997 , and in colder season in south-west slope in 1926, 1947, 1957, 1970, 1998. Floods in 1998, 2001, 2008 and 2014 were especially harmful. Local catastrophic floods happed every 2 or 3 years or even annually.

The floods start to form when precipitations exceed $20 \mathrm{~mm}$ daily. During intensive rainfall with precipitations over 100 $\mathrm{mm}$ per day the floods are catastrophic. In this case water levels exceed 2-4 $\mathrm{m}$ in mountainous terrains, 5-6 $\mathrm{m}$ in the foothills, and $6,5-9.5 \mathrm{~m}$ in the Tisza river. Such high floods cause the overlow of towns and villages, agricultural lands, and factories. The width of these inundations can reach up to $50-60 \mathrm{~m}$ in small rivers, $115-200 \mathrm{~m}$ in medium-sized, while in the Carpathian foothills in large rivers it can exceed 2500 $\mathrm{m}$, especially in plain area, and even more. The speed of flowing water in this time depends on values of maximum water loss, slope and rigidity of the riverbed (Obodovsky O.G., 2001).

Observations and the analysis of studies of many years show that floods and other dangerous natural phenomena in Ukraine happen as result of a row of both natural and anthropogenic factors (Galay V. I., 1983). The most important among these factors are hydrometeorological. Combined with characteristics of watershed surface, including steepness and magnitude of slopes, small depth of bedrocks, low ability of shallow soils to accumulate water, and ruggedness of the terrain, these factors play key role in catastrophic events (Hooke J. M., 2006).

In addition, economic activity in the basins of the Dniester and Tisza in recent decades reinforced the effects of natural factors that lead to the occurrence of floods, increased their strength and the extent of caused damage. The formation of such high floods in the Carpathian region is caused by other than purely physical-geographical and meteorological factors and includes the number of man-made factors, such as construction of dams, which changes conditions of river waterflow. Building activity and construction of hydraulic structures in the area of permanent flooding increase adverse effects. Additionally, state of economic activity on the slopes of river valleys, including areas of formation of the flow, especially in places of logging also effects to the intensification of flood, landslide and mudflow processes ( $\mathrm{J}$. Hamar, 1999).

Uncontrolled deforestation, particularly during the second half of 20th - beginning of 21 st century that destroyed more than 100,000 hectares of forest is one of the main reasons of natural disasters happening in the Carpathian region. A healthy forest can sustain most part of flood waters, however when forest is absent the environment takes all the power of a flood. Natural disasters cannot be prevented completely, but their influence can be weakened and localized. Timely warnings can minimize the material losses. This can be achieved through operational monitoring and forecasting of flood situation, construction and strengthening of dams, timely warning of the possibility and extent of flooding.

\section{RESEARCH}

With the passage of time riverbed can change its location (Grenfell M.C., 2013). Various natural and anthropogenic factors influence this. As for anthropogenic factors, their number can be significantly reduced through compliance with community water conservation restrictions. Such restrictions are created in order to protect water objects from pollution and excessive construction, leading to the weakening and destruction of the coast waters. The use of remote sensing and GIS technology opens new opportunities for studying fluvial flood events (Burshtynska Kh., 2000).

Aerospace visual monitoring is based on the use of materials of space imaging, aerial survey, data of laser scanning and radar imaging, cartographic materials - topographical plans and maps, special maps - soil and geological, surveying and engineering measurements in rivers, in particular the groundbased observations.

Monitoring of channel processes should be conducted especially after disastrous floods, as they may change the 
type of riverbed and be accompanied by significant deformation and erosion processes in river itself and its basin area (Zolezzi, 2012).

\section{General characteristic of rivers Dniester and Tisza of the Carpathian region}

Dniester is the largest river in several Ukrainian oblasts. It originates on the northwest slope of Mount Rozluch (Carpathian region) at an altitude of $760 \mathrm{~m}$ above sea level. Its river system is the most dense in the Carpathian part of the basin. Its riverbed is very meandering. Dniester has many tributaries. Stryi, Svicha, Limnytsya, Bystrytsa, Zolota Lypa, Seret, Zbruch, are the largest (Baseyn richky Dnister, 2015. http://dpbuvr.gov.ua). Dniester is $1362 \mathrm{~km}$ long. Its length in Ukraine is $912 \mathrm{~km}$, ending in the Dniester Estuary. The square of its basin is $72900 \mathrm{~km}^{2}$, of which $53490 \mathrm{~km}^{2}$ or $73 \%$ is located within Ukraine. Its water basin occupies $9 \%$ of Ukrainian territory, making its volume of water the second largest in Ukraine. The Dniester in its upper part is a typical mountain river with $\mathrm{V}$-shaped deep valley. The width of the channel is up to $40 \mathrm{~m}$ and it is streaming to the north through rocky banks. In plain area the river firstly flows through a swampy valley, which is up to $13 \mathrm{~km}$ wide, and then bumps into the Podillya Plateau. The valley of Dniester in its middle is quite narrow, winding, and full of picturesque landscapes. The floodplain of Dniester is dissected by many tributaries. The width of its valley near its estuary is $16-22 \mathrm{~km}$. The mountainous and foothill parts of the Dniester basin with mostly right bound tribal arias occupy $9 \%$ of its area.

All rivers of the Zakarpattya region belong to the basin of Tisza, Danube's largest tributary. Tisza's length is $966 \mathrm{~km}$ (201 km within the Zakarpattya region). Its main tributaries are the rivers Kosovska, Teresva, Tereblya, Rika and Borzhava. The area of its basin within the Zakarpattya region is $12760 \mathrm{~km}^{2}$ (general $-156400 \mathrm{~km}^{2}$ ). Tisza's upper, mostly right-bank part is located within Ukraine, occupying the south-eastern slope of the Ukrainian Carpathians and the Zakarpattya lowland. Its valley in the mountainous part is Vshaped (100-200 $\mathrm{m}$ wide) and in some parts gorge shaped (30-50 $\mathrm{m}$ wide). Then it streams along the mountains of the Upper-Tisza lowland in a wide (from 3-5 to 8-9 km) valley, crosses the Volcanic ridge (here the width of the valley is reduced to $1,3-1,5 \mathrm{~km}$ ) and reaches the Zakarpattya lowland. The morphometric characteristics of the rivers Dniester and Tisza are in the chart below (Bilanyuk V.I., 2004).

\begin{tabular}{|l|c|c|}
\hline \multicolumn{1}{|c|}{$\begin{array}{c}\text { Morphometric } \\
\text { characteristics of } \\
\text { rivers }\end{array}$} & Dniester & Tisza \\
\hline $\begin{array}{l}\text { Length, km } \\
\text { Rate of flow, m/s } \\
\text { mountainous area }\end{array}$ & 1362 & 966 \\
medium current & $3-4$ & $3-4$ \\
lower part & $0,5-2$ & $1,5-3$ \\
Stream gradient, $\mathrm{m}$ & 0,7 & $0,6-1,2$ \\
Slope of the river, $\mathrm{m} / \mathrm{km}$ & 0,6 & 1325 \\
Morphometric & 1,4 \\
characteristics of & & \\
studied parts & 14,7 & 19,7 \\
Length, km & 7,2 & 14,4 \\
Straight length (between \\
final points of a region), & & \\
km & & 2 \\
Current, m/s & 27 & 19 \\
Stream gradient, $\mathrm{m}$ & 1,8 & 1 \\
Slope of the river, m/km & 2 & 1,4 \\
Tortuosity
\end{tabular}

Table 1. Morphometric characteristics of the rivers Dniester and Tisza

The floodplain in its upper part is absent or represented by a narrow $(30-60 \mathrm{~m})$ streak. In the lower part it becomes unilateral (from several dozens meters to $1,5-2 \mathrm{~km}$ ). There are also parts, surrounded by ramparts. The channel is the upper part is meandering. In the lower part it becomes very ramified with numerous islands. The Tisza acquires the features of a plain river when it enters the lowlands. Its breadth reaches $150-170 \mathrm{~m}$ (sometimes up to $260 \mathrm{~m}$ ) and its slope $-1,2 \mathrm{~m} / \mathrm{km}$.

\section{Methodology of research}

The task of the research is to elaborate the exploring methods for monitoring channel processes in the river Dniester and Tisza of the Carpathian region based on space images and cartographic materials, in particular in determining the displacement of riverbed areas.

To monitor the displacements of the river Dniester and Tisza, particularly in the transition year from the mountain to the plain of the river bed, we used the following materials:

- satellite images obtained from satellites: Landsat 5 (1992), Landsat 7 (2001) Landsat 8 (2014) and GeoEye (2009);

- topographic maps scale 1:100 $000(1889,1937,1986$, 1989), 1:2000 (1992, 2008);

- special maps: geological scale 1: 200 000, 1963; ground scale 1: 200,000, 1967, 1: 10000, 1987;

- materials of engineering and surveying work.

In the study we developed the flowchart for monitoring of channel processes of these rivers (Figure 1)

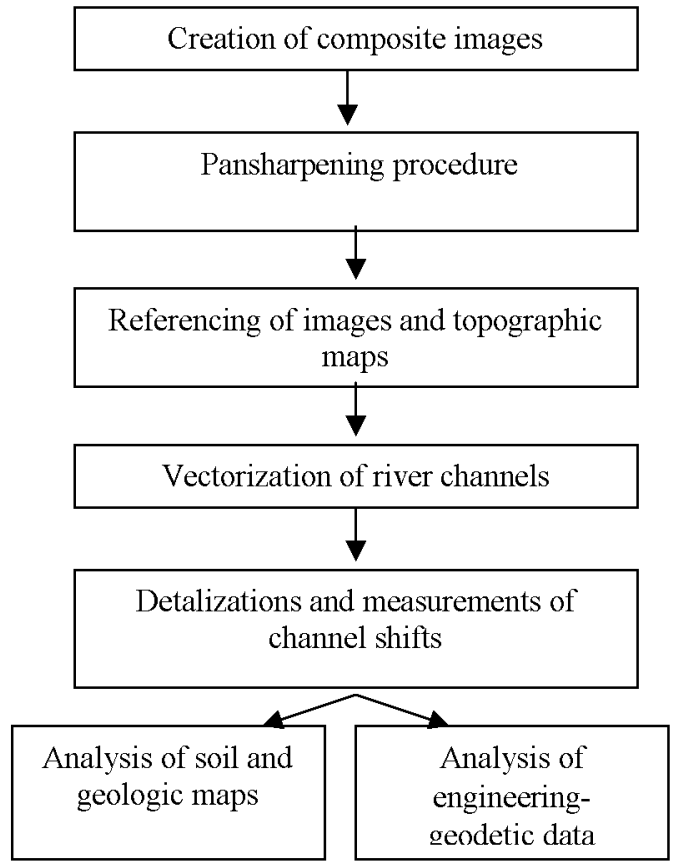

Figure 1. Flowchart of riverbed shifts monitoring for the rivers Dniester and Tisza

Global tasks relate to the planned shifts of riverbeds; for these tasks space images of middle resolution with easily visible drainage structure are used. For studies related to the determination of high accuracy deformation processes, especially in urban areas, we applied high resolution space images. High precision determination of deformation processes in riverbeds, including changes in topography, are possible through a ground-based geodetic work or field observations. The analysis of geological and soil maps allows to identify rocks, sediments and soils in the places of considerable shifts of the rivers.

Processing space images and cartographic materials is made in the software environment ArcGIS 9.3

The study of the displacements of the river Dniester.

Main components of the structural scheme are: obtaining the composite image of the river with maximum contrast from the coastal area; binding of topographical maps and satellite images; digitizing of the rivers' channels on materials of different time periods and the analysis of displacements. 
The comparison of available mapping information, data of field observations with satellite data has made it possible to trace the development of channel changes and reorganization for the rivers Dniester and Tisza of the Carpathian region in the last century

Space images of different years allow to evaluate the condition of riverbed with the assessment of its global changes. Effective interpretation of multispectral data of remote sensing of the Dniester depends on spectral characteristics of the objects on the surface of Earth.

Based on previous research (Burshtynska Kh., 2015), we established optimum band compositions for higher contrast of rivers comparing with image background. River channels are interpreted on images of satellite Landsat 5 for band composition: 1,3,4 and Landsat7, Landsat 8 for band composition: $2,5,7$. As it is known, multispectral channels of these imaging systems can get resolution on the ground up to 30 meters. For the increasing of resolution we applied a pansharpening technology. This makes it possible to increase the resolution up to $15 \mathrm{~m}$.

For the global monitoring of riverbeds shifts of Dniester and Tisza we used maps with the scale 1:100 000 and with precision of measurement of points on the terrain 10-15 m. Referencing of topographic maps and images has been carried out using 10 points, which could be identified on images and maps. These are, in particular, the points of crossing of railways and highways. For the referencing we used the 2 nd degree polynomial. Its error, obtained due to four redundant equations, did not exceed $15 \mathrm{~m}$. The evaluation of precision using control points was not carried out. The transformation were implemented to reference all materials with the coordinate system WGS-84.

The monitoring of the shift of Dniester from 1937 to 2014 (a 77 -year period) has been carried out on the $100 \mathrm{~km}$ long part of its channel, though main attention has been paid to the part on the east from Sambir with the largest sinuosity of the riverbed and, therefore, the most significant changes.

Figure 2 shows the shift of the riverbed according to space images from the satellites Landsat 5 (red color) and Landsat 7 (blue color), as well as 1989 topographic map (azure). Maximum changes have been detected on sections 1 and 2 . They reach $85 \mathrm{~m}$ in the first section from 1989 to 1992, and
$420 \mathrm{~m}$ in the second section over the same period. Large curve near railroad tracks is especially dangerous for the environment (section 1).

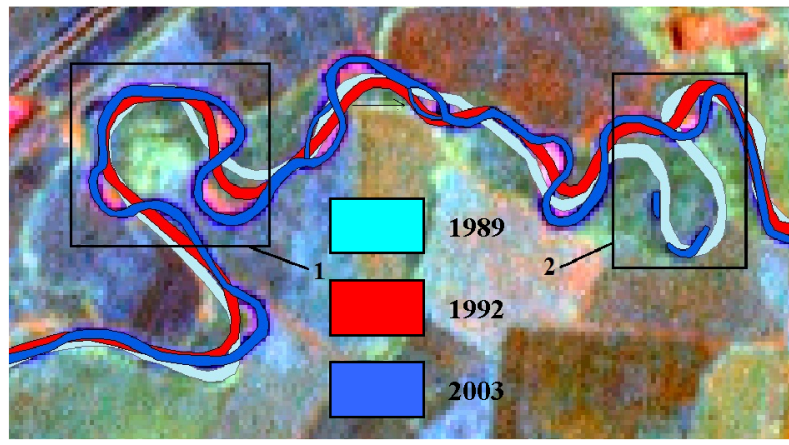

Figure 2. Digitized channels of the Dniester river in different years with the image of Landsat 7

The changes of riverbeds can be observed even at a relatively small 10 year period $(1992-2003)$, indicating instability of the channel and significant impact of flood events. Major floods occurred in the Carpathian region in 1998 and 2001.

Analyzing the topographic map of 1937 (Figure 3), we can explain such instability of the riverbed in the studied section by erosion of soils, which is represented by numerous ravines. The same Figure presents the results of analysis of the shift of Dniester's riverbed according to all available materials: the image of riverbed, digitized on the 1937 map, is in purple, and the satellite images of 2014 are in yellow. The type of colors of other images of the riverbed is the same as on Figure 2

The migration of riverbed to the side of the railway can be observed on section 1 . The section 2 shows a significant change of riverbed in 1989 (azure), compared to 1937.

In general, the river is inclined to meandering at the studied sector. Then, in 1992-2014 the river broke through the meander, returned to its original riverbed and left behind an oxbow lake.

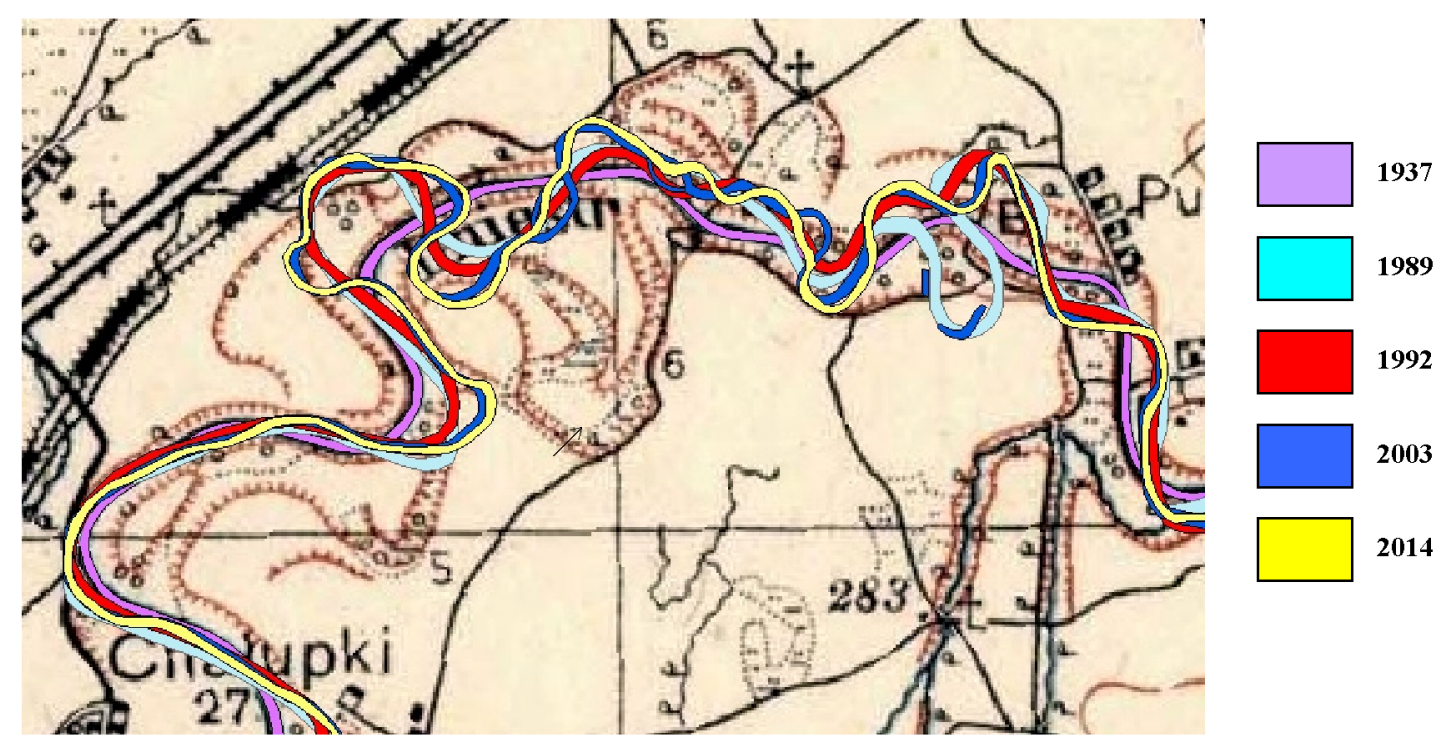

Figure 3. Digitized channels of the river Dniester over different years (from 1937 to 2014)

The section 1 portrays a systematic deviation of the riverbed to the right, caused by the erosion. Main deviations of the Dniester's riverbed at sections 1,2 are given on table 2 . We analyzed the changes in other parts of the riverbed in the mountainous area. In these places there could be observed a tendency of straightening of the riverbed, simplification of its configuration, dying away of its armlets, disappearance of alluvial gravel and sand lakes, and the emergence of lakes in the places of meanders.

The river Stryi is one of large tributaries of the Dniester and flows near the city of Stryi (district center in Lviv region). The monitoring of rivers in urban places has its specificity, 
because people there constantly take out construction materials, including stone, gravel and sand, as well as do unauthorized construction. The monitoring of deformation processes of rivers in the urbanized areas requires highprecision imaging. According to the data, obtained from satellites Landsat 5 and Landsat 7 it is possible to determine only general routine changes of riverbed. For the monitoring of the part of river Stryi we used an image, obtained from the space carrier GeoEye (2009) with resolution 0,41 m, as well as topographic plans of the scale1:2000, made in 1992 and 2008. These materials served for creation digital elevation model (DEM). They made it possible to determine the changes of microrelief along the river and its morphometric characteristics.

Using the topographic plans of different years and space images from the satellite GeoEye, we analyzed the changes with the Stryi's riverbed over the 17-year period.

The topographic plans were exported in the software package ArcGis 9.3 for a further analysis. Their binding to the GeoEye's space image has been made in the coordinate system WGS-84 according to distinctive points, picked up over the whole territory of this region, such as crossroads, bridges and power lines. The precision of binding by 10 identified points ( 4 surplus equations) has made $0,5 \mathrm{~m}$ by inner convergence (Shevchuk V., 2011)

The figure 4 depicts a digitized channel of the river Stryi (its riverbed by the 1992 topographic plan is given in red, by the 2008 topographic plan - in green, and by space image of 2009 - in yellow)

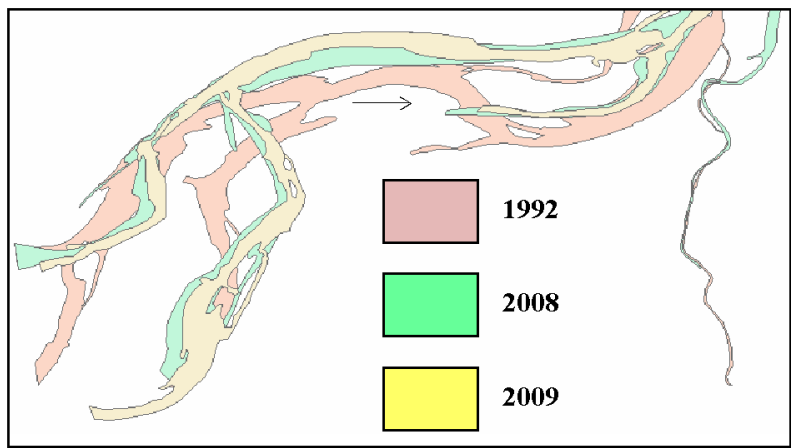

Figure 4. A comparative image of the Stryi river channel according to the topographic plans of 1992,2008 and space image of 2009

The analysis allows to conclude that in this area the riverbed is weak. Its maximum shifts over 17 years amount to $100-130$ $\mathrm{m}$. The change of its configuration is largely due to strong floods and anthropogenic activity. Therefore, considering small angles of the slope of coastal areas (up to $1-2^{\circ}$ ), we can assume that generally the floods of 1997, 1998, 2001, 2004 and, especially, 2008 caused this phenomenon.
In order to compare obtained results and analyze the correctness of applied methods we used materials of engineering and geodetic works. For this we used transversal and longitudinal profiles of the river over the years 2003, 2008 and 2010 of scales: horizontal 1:500, vertical 1:200 and obtained quantified data about the change of the Stryi's riverbed near the city of Stryi and suburban villages. Because of the lack of space in the paper, we can't provide here the materials of engineering and geodetic studies. However, we have to mention that the shift of Stryi's riverbed over the period of 7 years, according to these materials, is $50-60 \mathrm{~m}$. We implement comparison of shifts, obtained using theses 2 different data sets (first: space images and topographic maps, and second: engineering and geodetic materials). It certifies the efficacy of the proposed approach to the analysis of riverbed processes.

The analysis of the shift of Tisza's riverbed

The analysis of the shift of Tisza's riverbed is analogous to Dniester.

On figure 5 one can see images of Tisza's riverbed near the city of Khust, which are digitized based on topographic maps of 1986 (azure) and 1889 (green).

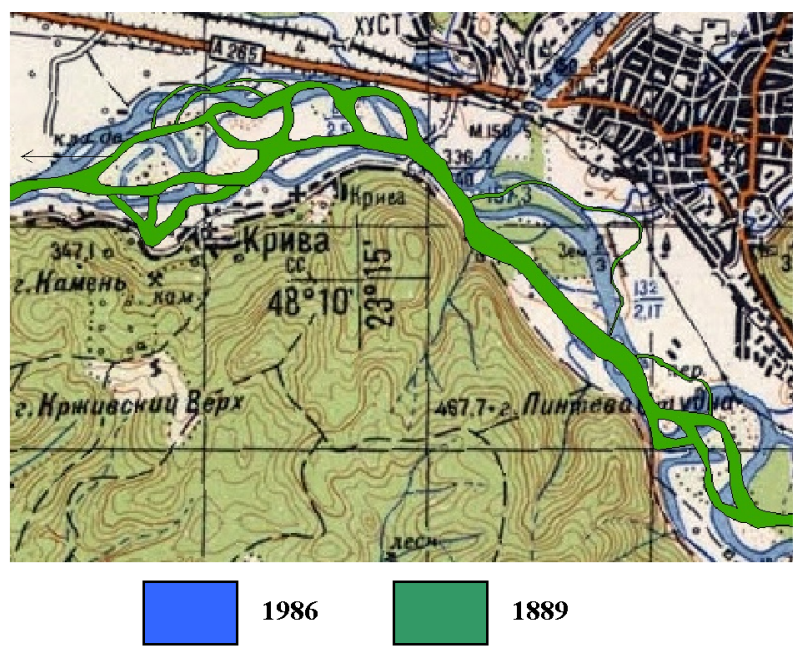

Figure 5. Digitized Tisza's riverbeds, according to the maps of 1889 and 1986

The analysis of topographic map with these riverbeds certifies that the river bends around a mountainous region, while it runs into the Zakarpattya lowland. Its riverbed is unstable and braided in the northern part of the map. We note the formation of meanders and large deviations of its riverbed near the place of Tisza's meeting with its tributary Rika.

Even the space images of Tisza's riverbed, obtained from satellites Landsat 5 (2003) and Landsat 8 (2014) over the 11year period (figure 6), which almost overlap, show a significant migration of riverbed in the north-west part of the image.

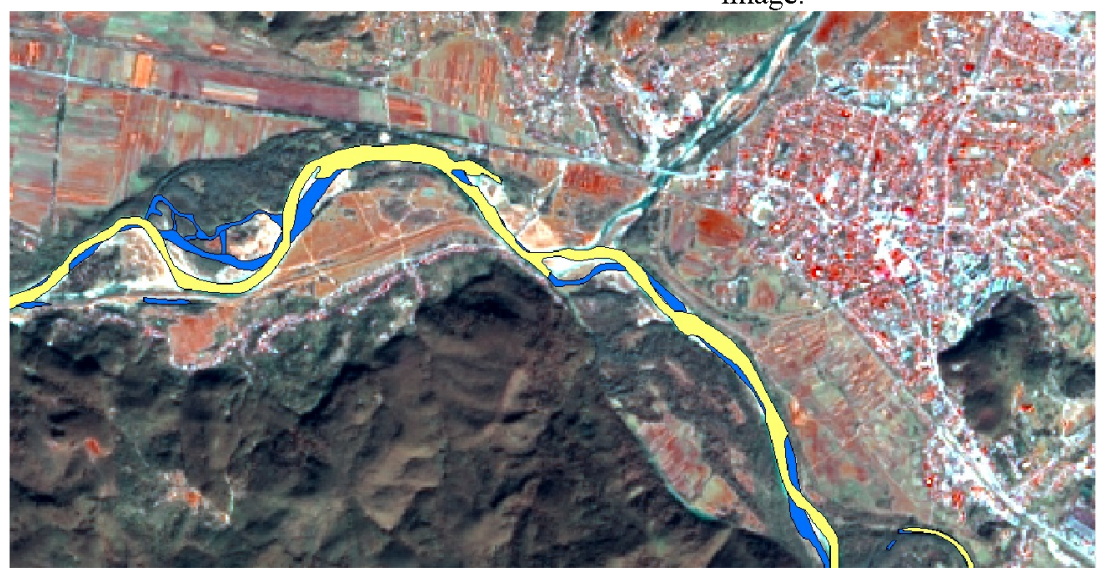

Figure 6. The Tisza's riverbed according to space images by Landsat 5 (blue) and Landsat 8 (yellow) 
The International Archives of the Photogrammetry, Remote Sensing and Spatial Information Sciences, Volume XLI-B7, 2016 XXIII ISPRS Congress, 12-19 July 2016, Prague, Czech Republic

We make a more detailed analysis of the shift of Tisza's riverbed on Figure 6, which shows its channels imposed over each other over different time periods. The images have been obtained from Landsat 8 in 2014 and digitized by the software package ArcGIS. Figure 7 presents the following range of colors: green (on the 1889 topographic map), blue (on the 1986 map), red (on the 1992 space image), blue (on the 2003 space image), yellow (on the 2014 space image). We observe a tendency of deviation of the Tisza's riverbed from the mountains to the lowlands and the erosion of its shore. The displacements reach $250-350 \mathrm{~m}$ with maximum values of 500-1000 m. Channel processes are characterized by meandering (section 1,2 ). On section 2 we observe the formation of oxbow lakes, which left after meandering of 1986 and 1992 (Table 2).

\begin{tabular}{|c|c|c|c|}
\hline \multirow[t]{2}{*}{$\begin{array}{l}\text { Name of } \\
\text { the river }\end{array}$} & \multirow[t]{2}{*}{$\begin{array}{c}\text { Years of } \\
\text { observation }\end{array}$} & \multicolumn{2}{|c|}{$\begin{array}{c}\text { Channel } \\
\text { displacement, } \mathrm{m}\end{array}$} \\
\hline & & Section №l & Section №2 \\
\hline \multirow{3}{*}{ Dniester } & $1937-1989$ & 150 & 370 \\
\hline & $1989-1992$ & 75 & 420 \\
\hline & $1992-2003$ & 85 & 30 \\
\hline \multirow{5}{*}{ Tisza } & $2003-2014$ & 15 & 30 \\
\hline & $1889-1986$ & 570 & 380 \\
\hline & $1986-1992$ & 45 & 930 \\
\hline & $1992-2003$ & 30 & 195 \\
\hline & $2003-2014$ & 15 & 15 \\
\hline
\end{tabular}

Table 2. Values of displacement of riverbeds of Dniester and Tisza

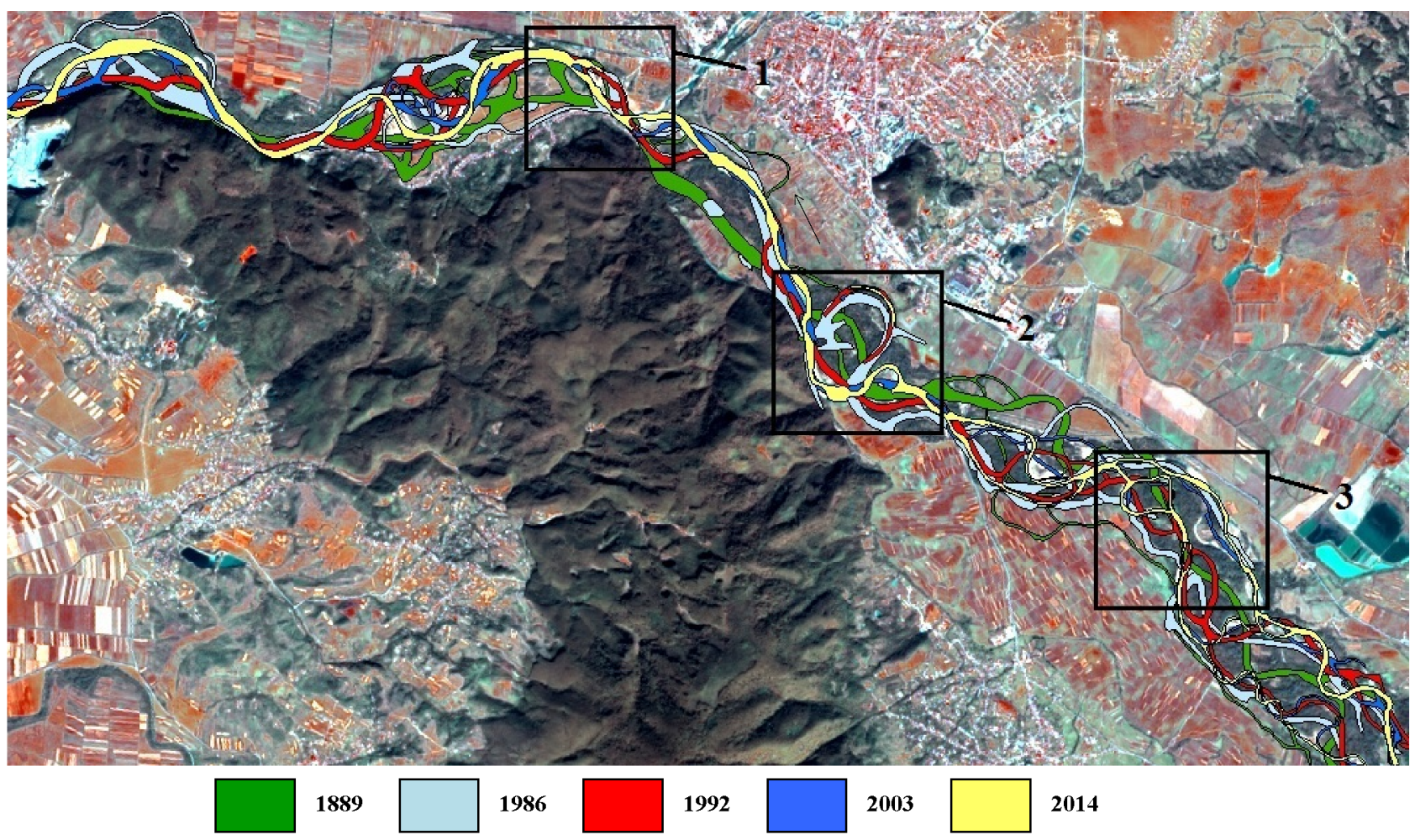

Figure 7. Tisza's riverbed over different years (from 1889 to 2014)

We can conclude from the analysis of topographic map of 1986 that one of the braids of the river almost approaches the main highway. A danger of Khust inundation inclined its municipalities to conduct a series of hydroengineering works on sections 2 and 3 of the river, as it is shown by the change of its channel according to the 2014 image. However, the flood in the Zakarpattya region in 1998, when the level of water raised to 5 meters, and floods in 2001, 2008 and 2010 caused the instability of channel and the destruction of hydraulic structures and highways. Such situation demands a constant monitoring of channel processes and large funds for regulation of the riverbed (Obodovsky O.G., 2005)

Today hydraulic works are not efficient enough, as testified by image of the riverbed on section 1 , where the river almost touches the main highway. Even now, while these materials are prepared for the publication, media report about the winter flood on Tisza and its tributary Teresva. The level of water rose to $4 \mathrm{~m}$ on these rivers and caused great damage to infrastructure.

\section{The analysis of geological and soil maps}

The analysis of geological and soil maps in the places of significant riverbed migrations of the rivers Dniester and Tisza during the transition of their mountainous part into the lowland testifies the presence of soft rocks and sediments. They erode easily, facilitating a significant change of riverbeds during floods, especially catastrophic. Sand and gravel materials and clay are exploited, often unlawfully, in the riverbed and the floodplain without control, causing the deformation of both the riverbed and its shores.

There are mostly brown forest, sod and brownsoil, and lightloamy types of soil near the Dniester river. The presence of alluvium and diluvium in the places of their bedding indicates the processes of erosion, caused by strong rains. Soils that are light according to their mechanical composition are often blurred, especially during floods, facilitating the development of erosive processes both in the riverbed and the riverine territory.

Turf-loam soils are mostly present in clay alluvial sediments, meadow and podzolized - in sandy and medium-loany sediments, and meadow soils - in sandy-loam sediments. During excessive moisture it causes swamping of river valleys, while during floods these soils erode easily.

The proposed methodology of riverbeds monitoring can be used by administrative departments of water management, research institutes and other bodies engaged in carrying out repair works of bank protection and regulation of riverbeds. 


\section{CONCLUSIONS}

1. Main factors, which influence the shift of riverbeds of Dniester and Tisza, are physical and geographical, and meteorological factors, including flood events, as well as anthropogenic factors, including logging, construction of floodlands, and ecological abuse.

2. The study of riverbed shifts, conducted according to space images of the satellites Landsat 5 (1992), Landsat 7 (2003), Landsat 8 (2014) and GeoEye (2009), and topographic maps of scale 1: $100000(1998,1937.1986,1989)$ for the Dniester (an 80-year period) and the Tisza (a 125-period) certifies about significant shifts of their riverbeds, especially during the transition from a mountainous to the lowland part, which reach $420 \mathrm{~m}$ for the Dniester and $1000 \mathrm{~m}$ for the Tisza. The monitoring has been conducted on the $100 \mathrm{~km}$ part of these rivers.

3. We used geological and soil maps for the analysis of riverbed shifts. It allows to conclude that these riverbeds are weak and braided. It causes severe meandering and the formation of oxbow lakes.

4. The efficiency of the proposed methods of studying riverbed shifts is confirmed by the materials of engineering and geodetic works.

5. The analysis of riverbed shifts after the flood events testifies about the low efficiency of hydraulic works, which often cause a breakout of dams and destruction of hydroengineering structures.

\section{REFERENCES}

Baseyn richky Dnister. Fizyko-geografichni umovy formuvannya stoku. 2015. http://dpbuvr.gov.ua.

Bilanyuk V.I., 2004: Praktykum iz zagalnoyi gidrologiyi. http://geoknigi.com/book_view.php?id=267.

Burshtynska Kh., Movchko L., Shevchuk V., 2015: Monitoryng ruslovyh protsesiv ta povenevyh yavyshch riky Dnister za kosmichnymy zobrazhennyamy. Suchasni dosyagnennya geodezychnoi nauky ta vyrobnytstva. Zbirnyk naukovych prats'. Vypusk I (29), pp. 124-128.

Burshtynska Kh., O. Tumska, D. Lelukh, 2000: Computer Technology of Determination of Area of Digital Elevation Model. In:19 ${ }^{\text {th }}$ ISPRS Congress, Vol. XXXIII Work, Gr. IV, Amsterdam, pp. 148-153.

Galay V. I., 1983: Causes of riverbed degradation. Water Resources Researched, Vol. 9, № 5. pp. 1057-1090.

Grenfell M.C., 2013: Mediative adjustment of river dynamics: The role of chute channels in tropical sand-bed meandering rivers. Sedimentary Geology, http://dx.doi.org/10.1016/j.sedgeo.2013.06.007.

Hooke J. M., 2006: Hydromorphological adjustment in meandering river systems and the role of flood events. Sediment Dynamics and the Hydromorphology of Fluvial Systems (Proceedings of a symposium held in Dundee, UK, July 2006). IAHS Publ. 306.

J. Hamar and A. Sárkány-Kiss, 1999: The Upper Tisa Valley. Preparatory Proposal for Ramsar Site Designation and an Ecological Background. Szeged. p. 502.

Obodovsky O.G., 2001: Gidrologo-ekologichna otsinka ruslovyh protsesiv (na prykladi richok Ukrayiny). K.: NikaTsentr. p. 274.
Obodovsky O.G., V.V. Onyshchyk, O.E. Yaroshevych, 2005: Analiz ruslovyh protsesiv ta rekomendatsii shchodo upravlinnya ruslozaplavnym kompleksom na peredgirnorivnynniy dilyantsi r. Tysy. Gidrologiya, girdohimiya $i$ gidroekologiya. Nauk. Zbirnyk. Tom 7. pp. $69-88$.

Shevchuk V.M., Burshtynska Kh. V., 2011: Metodyka monitoryngu rik na urbanizovanyh terytoriyah. Geodeziya, kartografiya $i$ aeroznimannya. Mizhvidomchyy naukovotehnichnyy zbirnyk. № 75. pp. 73-82.

Zolezzi, G., R. Luchi, and M. Tubino, 2012: Modeling morphodynamic processes in meandering rivers with spatial width variations, Rev. Geophys., 50, RG4005, doi:10.1029/2012RG000392. 